\title{
Fifteen Years of Experience from a Medical School' Clinical Skills Laboratory
}

\author{
Quinze Anos de Experiência do Laboratório de Aptidões \\ Clínicas de uma Escola Médica
}

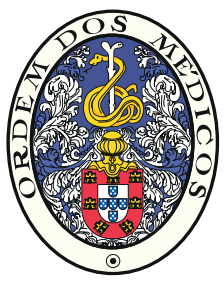

\author{
José Miguel PÊGO ${ }^{1,2}$, João José CERQUEIRA $\bigotimes^{1,2}$, João BESSA ${ }^{1,2}$, Vitor Hugo PEREIRA ${ }^{1,2}$, Sara GOMES ${ }^{1,2}$, \\ José MARIZ1,2, Rita SOUSA ${ }^{1,2}$, Pedro MORGADO ${ }^{1,2}$, Nuno SOUSA ${ }^{1,2}$ \\ Acta Med Port 2017 Feb;30(2):85-92 - http://dx.doi.org/10.20344/amp.8408
}

\section{ABSTRACT}

Introduction: Medical Education has evolved being defined as a continuum of the medical training from the pre- to the post-graduate period and through a lifetime of medical practice that is mirrored in the competencies framework that several international institutions have established. This creates a challenge to educational institutions (pre- and post-graduate) that traditionally take separate pathways Material and Methods: The present report is a description of the efforts carried by the School of Medicine of the University of Minho to implement a strategy of teaching/learning methods that follows modern standards towards constructive alignment of the medical curriculum, from the pre- to the post-graduate. The faculty members responsible for these activities make a narrative self-report of the activities developed and where available quantitative data from participant surveys are presented.

Results: In order to achieve a constructive alignment of educational/assessment strategies several steps were taken that focused on the revision of the learning goals, teaching methodologies and assessment strategies. This implicated the investment in the training/ certification of faculty, acquisition of simulation tools and a dedicated infrastructure. Alumni were a fundamental cornerstone as voluntary faculty contributing to pre-graduate training, but also training their own scholar skills. Overall, courses are rate with a high rate of satisfaction among course participants.

Discussion: Setting up the present teaching/learning environment of the School of Medicine of the University of Minho required a collective effort of the faculty, as well a progressive investment in both acquisition of equipment and training of staff. These human and material efforts, however, lead to an excellent return in learning outcomes.

Conclusion: The main conclusion is that the constructive alignment of educational and assessment strategies towards the medical education continuum needs reflective thinking on the learners' needs. The secondary gain of these initiatives is to provide opportunities for junior doctors to practice teaching.

Keywords: Clinical Competence; Computer Simulation; Education, Medical/methods; Patient Simulation; Portugal; Simulation Training

\section{RESUMO}

Introdução: O conceito de Educação Médica tem evoluído sendo definido como um continuum do treino médico desde o pré- ao pós-graduado, prolongando-se por uma vida de prática médica que é espelhada na estrutura de competências que várias instituições internacionais estabeleceram. Isto cria um desafio às instituições de ensino (pre- e pós-graduado) que tradicionalmente funcionam separadamente.

Material e Métodos: O presente trabalho reporta os esforços executados pela Escola de Medicina da Universidade do Minho para implementar uma estratégia de métodos de ensino/aprendizagem que seguem os níveis de exigência modernos por forma a se atingir o alinhamento construtivo do currículo médico, desde o pré- ao pós-graduado. Os docentes responsáveis por estas atividades fazem uma narrativa auto reportada das atividades desenvolvidas e quando disponíveis dados quantitativos de inquéritos de avaliação.

Resultados: Por forma a atingir o alinhamento construtivo de estratégias educacionais/avaliação vários passos foram dados, que se focaram na revisão dos objetivos de aprendizagem, metodologias de ensino e estratégias de avaliação. Isto implicou o investimento no treino/cerificação dos docentes, aquisição de simuladores e estabelecimento de uma infraestrutura dedicada. Os alumni foram um pilar fundamental trabalhando como docentes voluntários e contribuindo para o treino dos alunos do pré-graduado, e adicionalmente treinando as suas próprias capacidades de ensino. Em geral, os cursos são avaliados com um elevado grau de satisfação entre os participantes dos cursos.

Discussão: Montar o atual ambiente de ensino/aprendizagem presente na Escola de Medicina da Universidade do Minho requereu um esforço coletivo dos docentes bem como o investimento progressivo em equipamento e treino da equipa. Estes esforços humanos e materiais, contudo, produziram excelente retorno em termos de resultados de aprendizagem.

Conclusão: A principal conclusão é que o alinhamento construtivo das estratégias educativas e de avaliação por forma a atingir as necessidades do continuum da educação médica exige um pensamento reflexivo nas necessidades dos estudantes. Um ganho secundário é que estas iniciativas providenciam oportunidades para médicos juniores praticarem o ensino.

Palavras-chave: Competência Clínica; Educação Médica/métodos; Portugal; Simulação por Computador; Simulação de Doente; Treino por Simulação

\section{INTRODUCTION}

Medical Education has evolved dramatically in the last decades. Several driving forces led these evolutions, including technical developments that allowed for better

learning tools and pressure from stakeholders namely patients, healthcare institutions, regulating authorities and medical doctors. Many medical school curricula

\footnotetext{
1. Life and Health Sciences Research Institute (ICVS). School of Medicine. University of Minho. Braga. Portugal.

2. ICVS/3Bs - PT Government Associate Laboratory. Braga/Guimarães. Portugal.

$\triangle$ Autor correspondente: João José Cerqueira. jcerqueira@med.uminho.pt

Recebido: 01 de novembro de 2016 - Aceite: 03 de dezembro de 2016 | Copyright $\odot$ Ordem dos Médicos 2017
} 
have evolved from the teacher-centered paradigm that characterizes classical methods, based on authoritative lecturers and mentors, to a student-centered learning process where the goal is not to pass on information but to capacitate the doctor-to-be with the tools and competences that are needed to continuously evolve towards the best practices and some, more recently, even to patient- (or systems-) centered approaches.

The continuity of the medical training from the pre- to the post-graduate period and through a lifetime of medical practice is mirrored in the competencies framework that several international institutions have established for the medical practitioner. One of the most commonly used, the CANMEDS $^{1}$ has been established by the Royal College of Physicians and Surgeons of Canada but others have been established by American (ACGME/ABMS) and UK counterparts (GMC). Despite differences in taxonomy and focus, they share a common vision of improving medical care by promoting competency-driven learning of all aspects of the medical profession and defining stages at which these are achieved. CANMEDS defines six domains of the medical profession that need to be mastered to become a medical expert: communicator, collaborator, leader, health advocate, scholar and professional. Additionally, it establishes a continuum from the pre- to the post-graduate education and lifelong learning a concept known as Continuous Medical Education (CME). These changes in medical education have, consequently, blurred the frontiers between pre- and post-graduate training.

The School of Medicine of the University of Minho (MedUM) was founded in 2000 and in its constitution, has imprinted the model of a student-centered approach to medical education, focused on the learning of the competencies through active learning and practice in accordance with Miller's ${ }^{2}$ notion that a medical professional must not only 'know' and 'know how' but also needs to demonstrate ('shows') and practice ('does'). To achieve these goals, the faculty have established an innovative curriculum based on an organ and system approach to content, by using modern learning methods like case-based learning, team-based learning, and by establishing a Clinical Skills Laboratory (CSL) that provides the ideal context for the practice of procedural (hard) and communication (soft) skills. These actions have been organized and instructed by faculty members and included in curricular and extracurricular activities. Besides the resident staff, the faculty includes several practicing doctors with no formal bound to the school that collaborate on a regular basis on the training of future medical doctors. Many of these are former students of the MedUM that see these encounters as opportunities to give back to students the knowledge that they once received and the possibility to learn and practice competencies as educators ('scholar').

The following is a description of the main projects organized by the CSL and how it is articulated between the MedUM, alumni and collaborators.

\section{MATERIAL AND METHODS}

The present manuscript was written has a self-report of each activity that have been established in the context of the CSL. The activities developed in the CSL have historically started has part of the MD Masters curriculum and evolved to the post-graduate field which is the approached that was chosen to be depicted in this report. Each section was written by the faculty responsible for each activity namely, João Cerqueira and José Miguel Pêgo for the pre-graduate activities, and in the post-graduate field, InAnesthesia (José Miguel Pêgo and Sara Gomes), iNeurology (João Cerqueira), iPsychiatry (João Bessa), iOrthopaedics (João Bessa), My Communication Skills (Pedro Morgado) and TIMI (José Mariz). Vitor Hugo Pereira is the president of the Alumni Medicina - Associação de Antigos Estudantes de Medicina da Universidade Do Minho (Alumni Medicina) reporting the impact of the partnership between the School and Alumni Medicina. Rita Sousa is a member of the Medical Students Association reporting on the student's
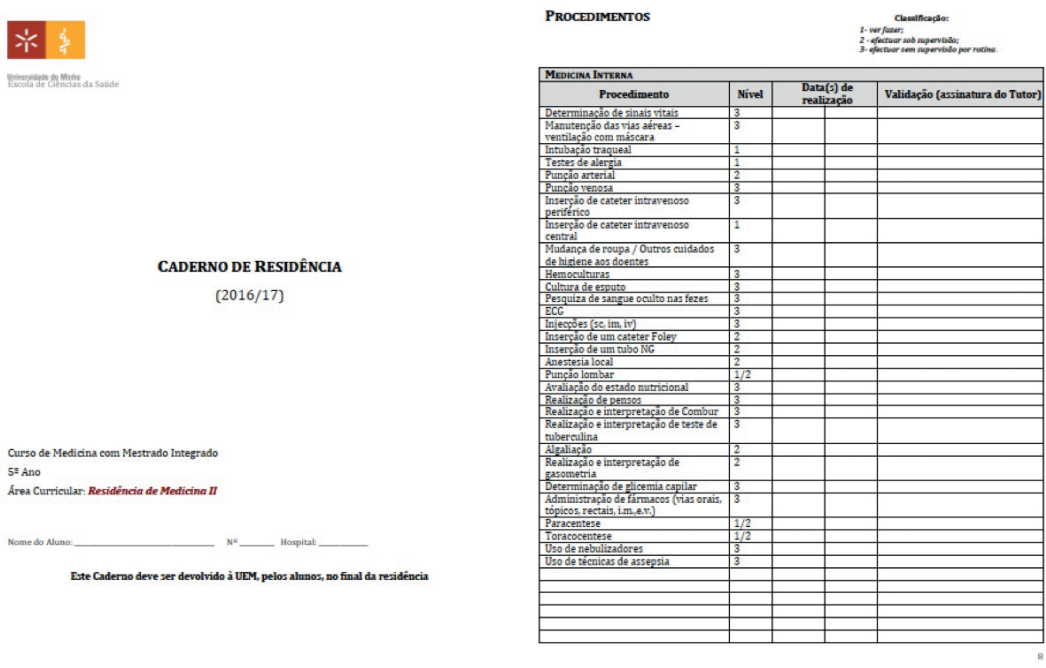

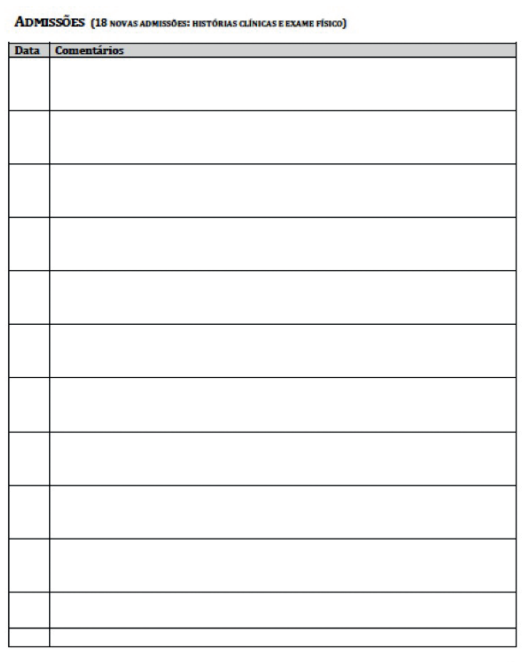

Figure 1 - Example of a student's logbook 
perspective. Courses are evaluated by participants using anonymous self-reported surveys based on Likert-scales of agreeance with statements. The results report to general satisfaction with courses and presented has frequencies.

\section{RESULTS}

\section{Pre-graduate activity: Curricular and extra-curricular} activities

Since its first cohort of students, in 2001, MedUM has included the training of clinical skills in a simulated environment. Core skills such as blood pressure measurement and auscultation were practiced in peers and supplemented by part-tasks trainers (breast palpation, cardiac sounds simulator) in what was the first infrastructure of the CSL, since year one of the MD Masters (Medical degree). The activities developed during this initial period where mainly directed at the curricular objectives, which were complemented by the classical training/observation during periods of hospital tutoring. These clinical gestures were recorded in a log-book (Fig. 1) that was periodically checked for progression.

In 2007, MedUM moves to its present facilities where a larger area is dedicated to simulation, with one briefing/ debriefing room and four satellite rooms. This investment was, additionally, supported by Gulbenkian Foundation that granted financial support to establish a Standardized Patient (SP) Program. During this transition period, a revision of the MD Masters curriculum was done and the educational program was redesigned in order to align the learning outcomes to the teaching methods and assessment strategies in accordance to the best practices. ${ }^{3}$ Several changes were gradually implemented in order to increase the weight of simulation in training and assessment. This increased activity demanded for the acquisition of several mannequins and simulators and the introduction of simulation-based activities in several curricular units. Additionally, a series of extra-curricular activities started being offered to students on a regular basis, after-hours, with the support of faculty members and voluntary instructors, mainly alumni of the school. Nowadays, the CSL occupies an area of $500 \mathrm{~m}^{2}$, counts with 15 different models of parttask trainers and three high-fidelity mannequins as well as several BLS mannequins and has extra-curricular activities

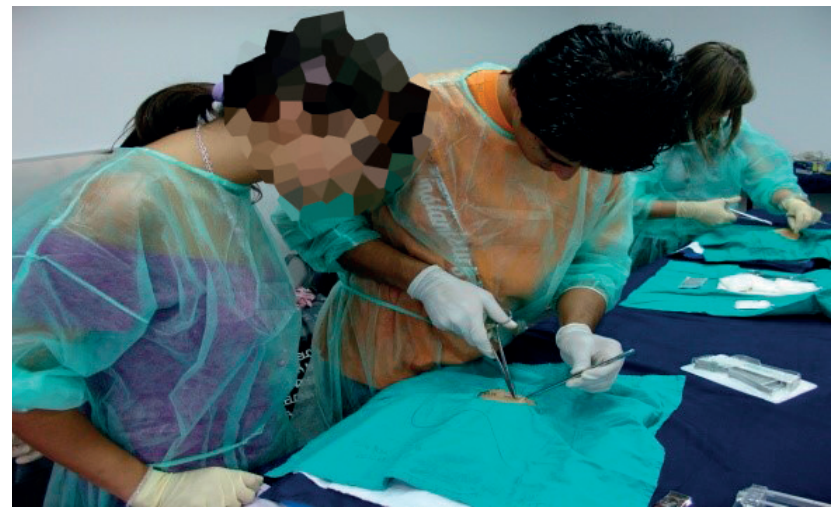

Figure 2 - Example of a CSL activity (suture workshop) on a daily basis during school days (Fig. 2)

MedUM was also the first medical school to establish a SP program in Portugal. After its kick-off in 2006, it was identified that the faculty lacked experience and certification. To overcome these pitfalls, in 2008, as part of a collaboration with the National Board of Medical Examiners, instructors from the USMLE Step 2CS program were brought to MedUM and provided guidance and training to severa faculty and voluntary staff in the construction of scenarios, SP training and checklist setting and scoring. ${ }^{4}$ Since then, the SP program has expanded and now includes more than 50 SPs, 100 clinical histories with validated checklists and a body of more than 40 well trained facilitators. One unforeseen challenge to the program has been the recruitment of SP. To overcome that challenge MedUM has put in place a strategy to recruit SP in the community using word-of-mouth, posters, flyers and by publicizing the program on the internet, namely through social networks. The SP recruitment program is now open all year, with a standardized workflow for prospective SP selection and training, and a continuous development program for both faculty/volunteers and SPs. Its ongoing research program has recently developed and validated a communication skills assessment scale, the first specifically designed for the assessment at the undergraduate level. ${ }^{5}$

The SP program has been the basis of several curricular activities incorporated in the MD Masters curriculum aiming to train the clinical interview and physical examination techniques, including a longitudinal training program on communication skills in different scenarios spanning the entire medical degree. As a secondary gain of this program, SPs were also used for the assessment of MD students in a model designated as Objective Structure Clinical Examination (OSCE), which is now the standard for the assessment of non-cognitive skills at MedUM. More recently, the SP program has also been pivotal in the training of communication skills in several postgraduate settings, from introductory courses for residents to specific communication trainings for a variety of healthcare professionals (nurses, pharmacists, physicians).

\section{Pre-graduate activity: Virtual patient programs}

In 2009, in order to promote clinical reasoning skills,

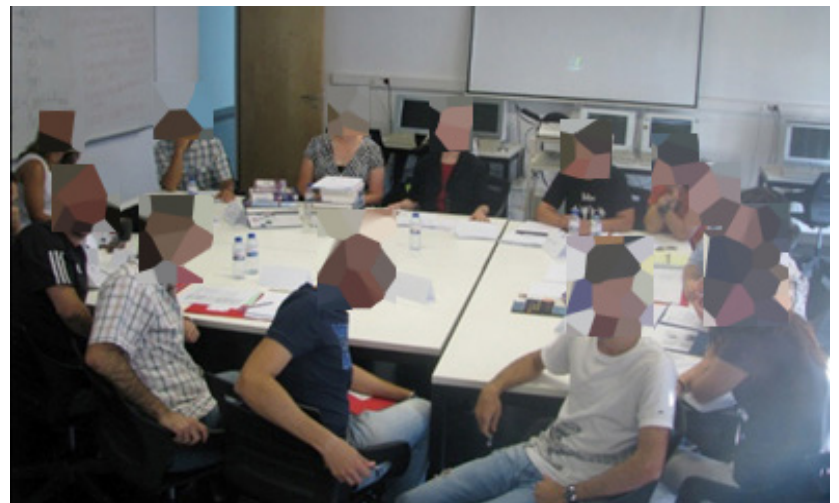

Figure 3 - Workshop on standardized patients 
MedUM implemented a web-based virtual patient platform, where clinical cases could be presented in an interactive way (including with multimedia content) and complemented with comments and/or questions. In the classroom, these allowed students to work at their own pace and was highly motivating and engaging, particularly when compared with traditional case-based presentations in which the entire class was working through the case at the same pace. ${ }^{6}$ More importantly, it also allowed the training of cost-benefit reasoning, by assigning a cost (either in time or in currency) to each selected option. Of note, besides its use in the clinical setting, virtual patients were also successfully used in the basic sciences to trigger the learning of relevant clinical correlations.

From 2015, the CSL has also been using a virtual patient table to organize sessions directed to the training of clinical reasoning. A virtual patient table is a simulator that creates problem-solving scenarios using virtual patients. These sessions use game-based learning to stimulate the participation and engagement of the students. We used this platform for the first time in the Cardiology rotation of our curriculum and the students provided excellent feedback. Around ninety five percent of the students agreed that the sessions were useful and that they had the chance to actively participate in the discussion of the cases. More than eighty-five percent of the students agreed that the virtual table interface is user-friendly and pleasant to use (Fig. 3). We are now developing a project to evaluate the impact of these sessions on student's performance during clinical years.

\section{Post-graduate activity: InAnesthesia}

The InAnesthesia project started in 2011. It is an intensive training program address to the early novice resident in anesthesiology and is presented in two modules (www. inanestesia.pt): Introduction to Clinical Anesthesiology and Advanced Course. The project has reached a national level, being recognized by the Portuguese Medical Association, Anesthesiology College, Portuguese Anaesthesiology Society, CAR - Clube the Anestesia Regional and the European Society of Anaesthesiology. The first module InAnesthesia - Introduction to Clinical Anesthesiology is presented in the first week of the residency program. During

\section{Self-perceived preparation}

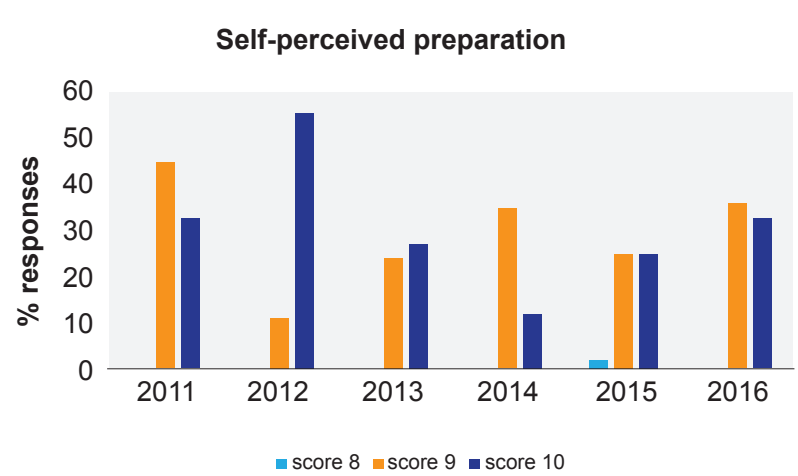

five intense work days, the residents have the opportunity to share knowledge and bound with fellow residents and specialist anesthesiologists from the entire country. During this course, participants learn the theoretical foundations to the training of Anesthesiology as well as training technical skills essential to anesthesia practice (arterial and venous cannulation, airway management, lumbar puncture, epidural block, etc.). Additionally, they contact with SP to learn the technique of clinical interview and how to handle the patient that is scheduled for an operation. The course also introduces trainees to specific-anesthesiology themes such as difficult airway management, fluid therapy, post-anesthesia-care, patient safety and quality and competency. ${ }^{7}$

This program has enrolled 200 residents and until now 51 facilitators have been involved, coming from $92 \%$ of the anesthesiology departments with training program. Ninety nine percent $(99 \%)$ of participants rated the course as 'Very Good/Excellent'. Many of the participants have now participated as instructors in several activities of the CSL directed at MD students, namely, Basic Life Support courses and technical skills closely related anesthesia (e.g. airway management, etc.). The course contributes not only for the preparation, but also for the self-perceived confidence to begin the training program, using a 10 points Likert scale.

The second module, InAnesthesia - Advanced Courses, is a high-fidelity simulation three-day program, for all levels of residency training, in which the participants are exposed to lifelike scenarios which depict complex situations common to anesthesiology practice, based in real cases. These scenarios are designed to train advanced techniques and most importantly, to train teamwork and communication skills in a concept designated by Crisis Resource Management. ${ }^{8}$ Until the present, 314 participants have been enrolled (Fig. 4).

\section{Post-graduate activity: iNeurology}

The ability to perform a precise and meaningful neurological exam is probably one of the most difficult tasks regarding the physical examination. Bearing this in mind, some of the first activities implemented in the CSL covered aspects of the neurological examination for undergraduate students, including both mandatory sessions (during the

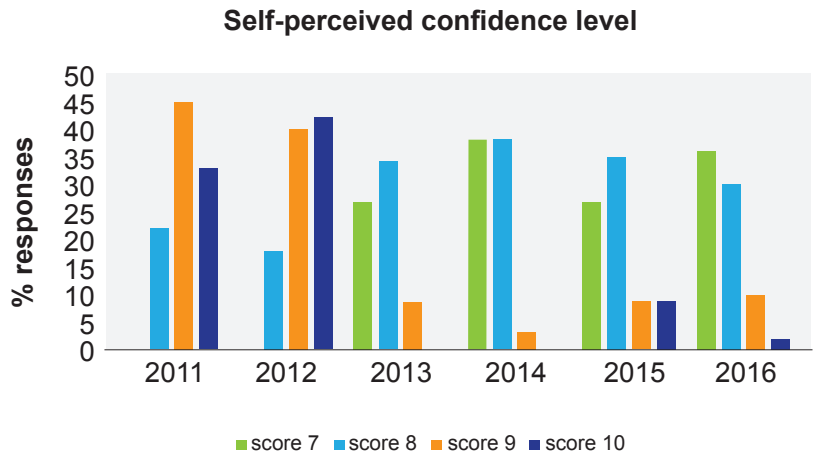

Figure 4 - inAnesthesia: results 
Nervous system module of Organic and Functional Systems III in the second year and Introduction to Clinical Medicine in the third year) and extra-curricular training sessions open to all students. The latter, in particular, were (and still are) highly popular among students ${ }^{9}$ and had a significant positive impact on students' performance. ${ }^{10}$ Having realized the impact of these training sessions and knowing that many graduates and entrant neurology residents were poorly confident in performing the neurological examination and dealing with the most common neurological emergencies, ${ }^{11}$ in 2013 we decided to design the iNeurology (iNeurologia), an introductory course for year one residents.

iNeurology is an hands-on introductory course for first year Neurology residents in Portugal that aims at helping residents rapidly acquire, at the start of their training, a core set of basic competencies in semiology, neurological examination and neurological emergencies. The program consists mainly of skills labs in the CSL, organized around three axes: communication skills, approach to the patient in the emergency room and ancillary techniques. These are complemented with short introductory seminars and a final skills-based assessment, used for constructive feedback (Fig 5A). Students rotate in small groups through the different stations, which are set up with SP, mannequins and high-fidelity simulators, guided by expert facilitators (2:1 ratio). The course is highly rated and valued by participants (Fig.s 5B, 5C). More importantly, it increases the confidence of first year residents in the core competencies: communicating (Fig. 5D), dealing with emergencies (Fig. $5 \mathrm{E}$ ) and performing ancillary techniques (Fig. 5F). In its four editions since 2013, iNeurology has trained 62 residents, covering more than $80 \%$ of the respective resident cohorts in Portugal and was rated excellent by more than $90 \%$ of the participants.

\section{Post-graduate activity: iPsychiatry}

iPsychiatry - Introduction to Psychiatry is an advanced course addressed to residents beginning their specialization

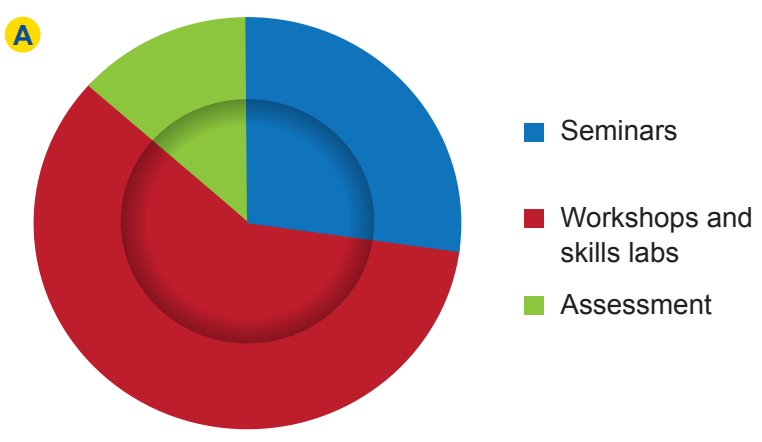

B Overall rating

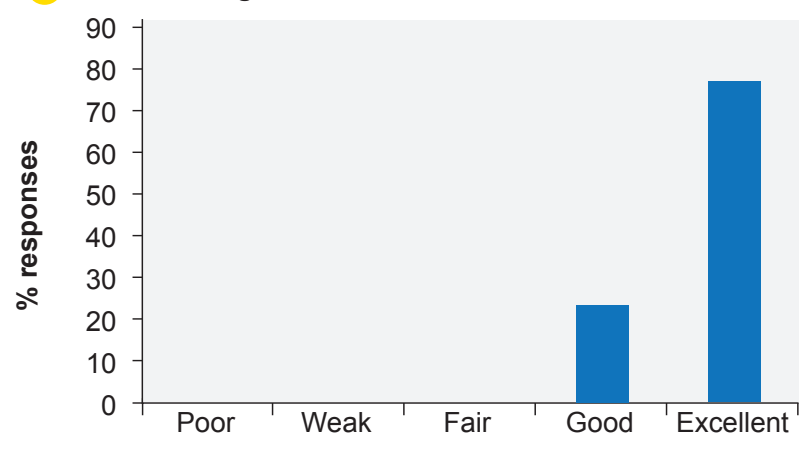

C Knowledge of the subject

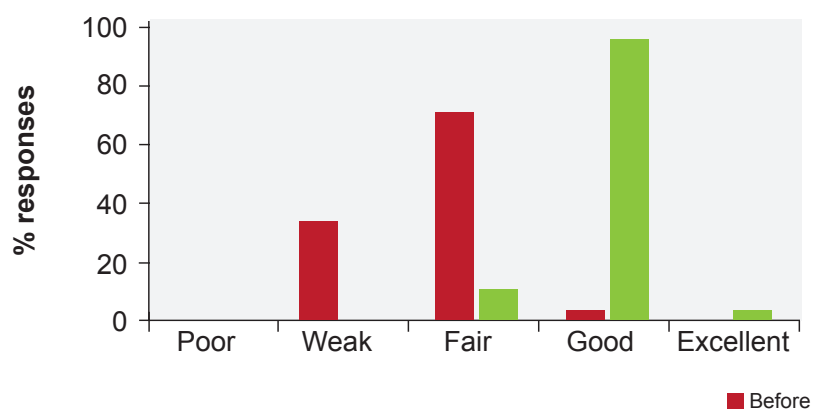

D Rate your confidence in dealing with:

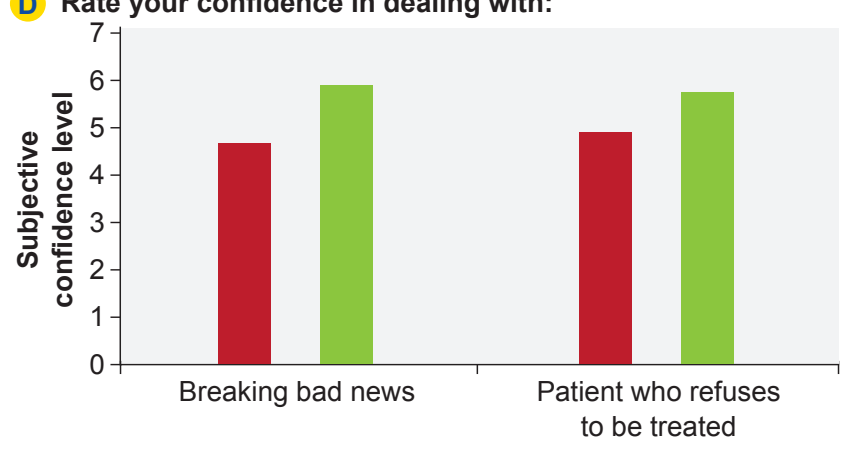

E Rate your confidence in dealing with:

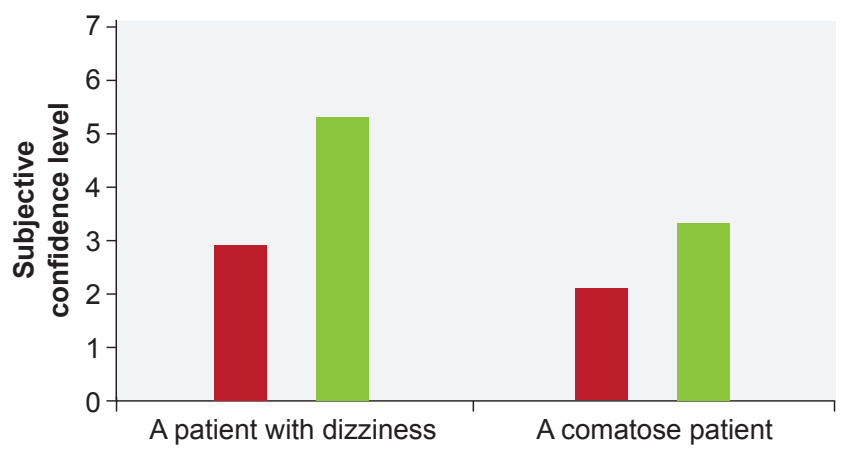

F Rate your confidence in performing:

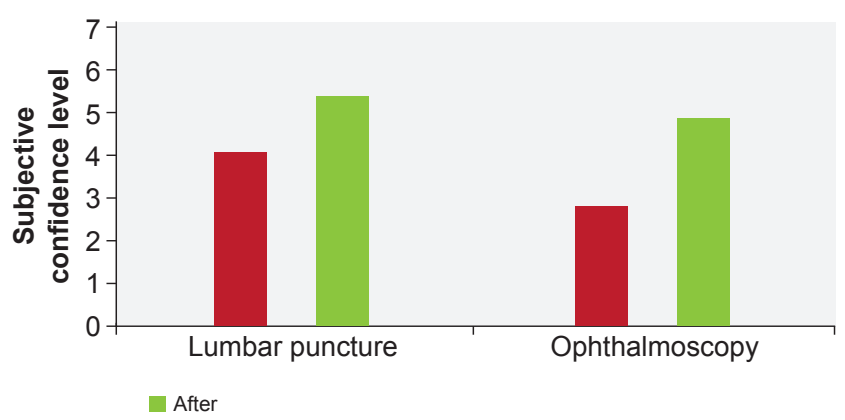

Figure 5 - iNeurology: results 
in Psychiatry. The innovative program was designed, combining clinical seminars in areas like psychopathology, psychotherapy and psychopharmacology, with practical sessions with SP in our clinical skills laboratory in which the residents have the opportunity to practice and develop skills related with communication, clinical interview and management of psychiatric emergencies.

In the four editions of this course, over 100 national residents of Psychiatry have participated in the training activities. In addition, some of these residents have joined the faculty to become involved in supervision of the practical sessions with SP in the clinical skills laboratory in following editions, working directly with their younger colleagues.

In 2015/2016 the course had its $4^{\text {th }}$ edition, with the participation of 40 residents, which corresponds to $73 \%$ of the national psychiatry residents. Both the clinical seminars and the practical training were highly rated by the participants (clinical seminars: 5\% very good, 95\% excellent; practical sessions: $2.5 \%$ very good, $97.5 \%$ excellent).

The ratings of the self-assessment questionnaires used to evaluate general knowledge and clinical skills in Psychiatry before and after the advanced course reveal a significant increase in the perception of residents regarding their abilities to cope with specific clinical scenarios in Psychiatry.12 This further emphasizes the importance of developing training activities in our clinical skills laboratory (Fig. 6).

\section{A Evaluation of the practical sessions}

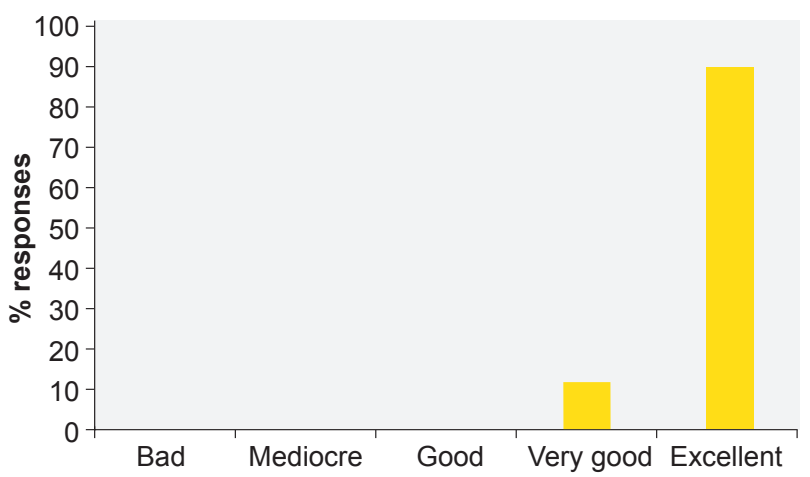

\section{Self-assessment of clinical skills}

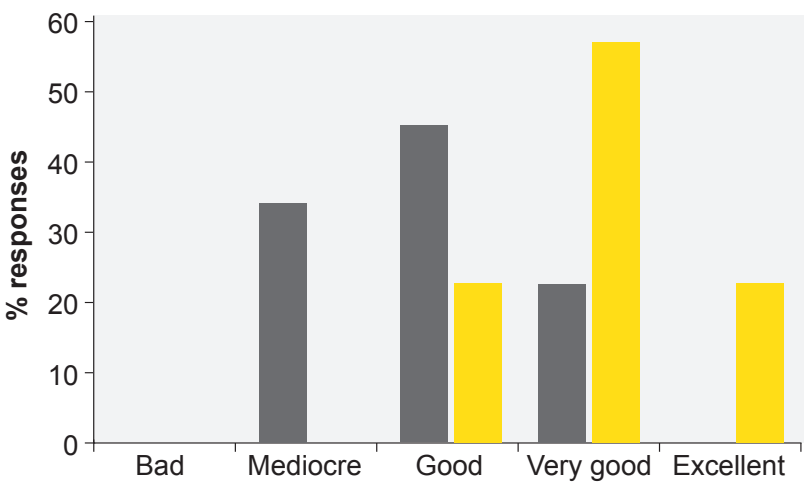

\section{Post-graduate activity: InOrthopaedics}

InOrthopaedics - Introduction to Orthopaedics is an advanced course addressed for residents beginning their specialization in Orthopaedics. This innovative training program was designed, combining clinical seminars in the major fields of Orthopaedics, with practical sessions in the surgical laboratory addressing the basic surgical techniques, practical sessions in the anatomy laboratory addressing dissection techniques in cadaveric material and practical sessions with SP in our clinical skills laboratory. In addition, during the duration of the advanced course, the residents had the opportunity to join a team based learning program in the pre-graduate training activities of the School of Medicine addressing the anatomy of the musculoskeletal system, working daily with medical students in the working groups defined to help guide and support the discussions and knowledge acquisition.

In the three editions of this course, over 40 national residents of Orthopaedics have participated in the training activities. The semi-structured interviews performed with residents after the advanced course revealed the importance of the practical sessions in the surgical, anatomy and clinical skills laboratories in the clinical and surgical skills acquisition. Furthermore, the interaction with pre-graduate medical students in the team based learning program addressing the anatomy of the musculoskeletal system was defined as an enriching experience that stimulated the

B Evaluation of clinical seminars

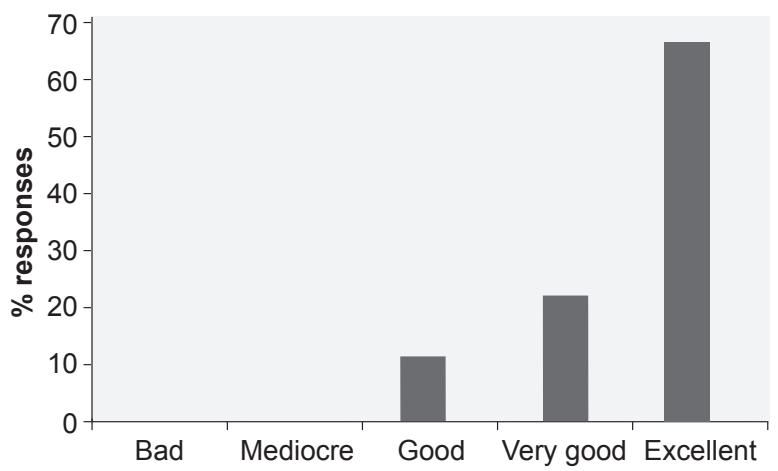

D Examination scores

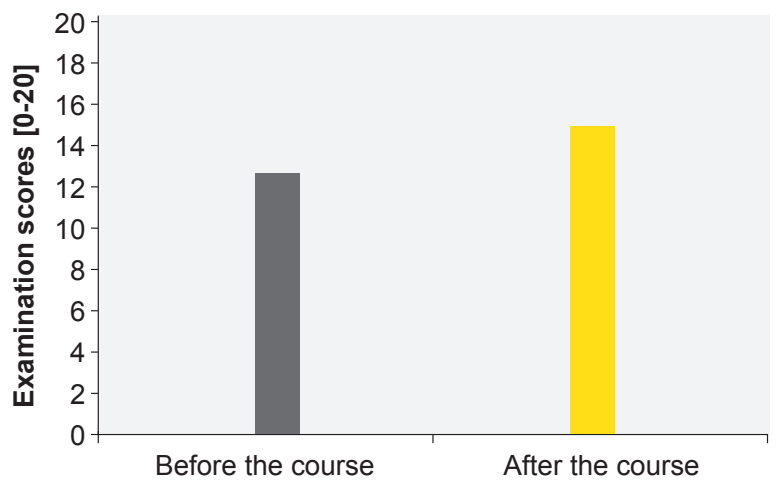

Figure 6 - iPsychiatry: results 
preparation in basic human anatomy and the development of teaching techniques. ${ }^{13}$

\section{Post-graduate activity: TIMI}

TIMI - Técnicas Invasivas em Medicina Interna (Invasive Medical Techniques in Internal Medicine) - is a postgraduate course for either residents beginning their specialization or specialists in Internal Medicine focused on the training of core invasive techniques for diagnostic, therapeutic and monitoring purposes. The course is based on the acquisition of technical procedures on the placement of central venous and arterial lines (with and without ultrasound), pleural drains, managing difficult intubation, lumbar puncture, using modern mannequin simulators and animal models. The simulation curriculum was designed to create a safe learning environment in psychomotor tasks, where the trainee can make mistakes and learn from them without the fear of harming the patient. The first edition was in 2012 and since then the course has had one to three editions per year, with some of the editions being held outside our laboratory. ${ }^{14}$ Each class involves small groups (4 - 5 participants for one tutor) to enhance a close tutor supervision and feedback, and begins with a short overview of the procedures including an introduction to the anatomy, tools used and technique, followed by hands on training. We have designed also smaller courses (one-day workshops), covering a less comprehensive curriculum (for example, addressing only intubation or ultrasound guided venous assessment).

In 2015/2016 the course had 69 participants (17.9\% first year residents, $42.9 \%$ second year, $21.4 \%$ third year, $7.1 \%$ fourth year, $10.7 \%$ fifth year), with all evaluating the course as very good $(57.1 \%)$ or excellent $(42.9 \%)$. When asked at the end of the course if they felt more confident to use the techniques in their daily practice, all the participants rated over 7 in a scale from 0 to $10(0$, not confident at all, 10 extremely confident; $7-9.7 \% ; 8-14.3 \% ; 9-52.4 \% ; 10$ $19 \%)$.

\section{Post-graduate activity: My Communication Skills}

The My Communication Skills (MCS) courses provide training for health professionals to enhance their communication skills and professionalism with patients and colleagues. These courses are versatile and can be tailored to the specific needs of participants including initial interview, breaking bad news, error disclosure, establishing rapport, conflict resolution, addressing disruptive behavior, communication in end-of-life situations, communication with child or elderly patients, communication with patients with disabilities, emotions management and communication with depressed or anxious patients. Using structured interactions with SP, participants learned to address communication failures, to utilize techniques to improve communication in difficult situations and to enhance communication skills and professionalism within clinical and non-clinical settings.

During the last two years, CSL organized $18 \mathrm{MCS}$ courses attended by a total of 387 health professionals, including medical doctors, nurses and pharmacists. The participants were asked to rate the courses and the analysis of the answers (both qualitative and quantitative) given on the evaluation forms confirms the impression left during the courses: $96 \%$ of the participants rated the course as 'excellent', $2 \%$ as 'very good' and $2 \%$ as 'good'.

\section{Alumni Medicina}

Alumni Medicina is a non-profit association that includes all alumni of School of Medicine providing a collective voice for its members and serving the best interests of alumni, students and faculty. Alumni Medicina works along MedUM either on co-organization of several post-graduate activities including InAnesthesia, INeurology, iPsychiatry, TIMI and My Communication Skills courses either on promotion of seminars, workshops and other scientific meetings. This association provides services on conference planning, program management, event strategy, marketing, registration management and accommodations. As partners, alumni benefit from a low registration fee, which increases the opportunity to keep the contact with the School of Medicine. Despite of high levels of participation by Minho's alumni, the percentage of participants who did not study MedUM has been increasing over the years and the positive feedback received has been raising the will to improve in further editions.

\section{Students' perspective}

The CSL is a valuable opportunity for every pre-graduate student. It is seen amongst students as a great asset where we can test and correct our pre-clinical and mostly our clinical skills (including communication skills) in a 'controlled environment' where each student can learn, train and retrain all these skills until it gets confident. This is done with the guidance of medical doctors that have experienced with this same CSL and know students' weaknesses and strengths very well, thus providing immediate and insightful feedback. It is also important for a pre-graduate student to learn procedures that will be needed in the hospital, where we are expected to know how to perform these procedures. Without the CSL, we wouldn't be as comfortable in the hospital during our rotations which also give us more liberty to focus on the patient rather than being concerned about these particular skills.

Another important aspect of the CSL is that everybody collaborates on this type of learning (including former peers); in fact, being taught by a former peer takes importance because the discussion starts on similar grounds and is quite relaxing for those who are learning the skill. Finally, even in higher stakes conditions, such as exams, the CSL provides a very useful context for the validation of our performance and, as a consequence, for our development as future medical doctors.

\section{DISCUSSION}

The present report is a description of the efforts carried by MedUM to design and implement a strategy of 
teaching/learning methods that follows the most modern standards towards constructive alignment of the medical curriculum, from the undergraduate to the post-graduate in a continuous manner. In order to achieve this goal MedUM took several steps that focused on the revision of the learning goals, teaching methodologies and assessment strategies. This implicated the investment in the training and certification of faculty, acquisition of several simulation tools and a dedicated infrastructure to these activities. It is also important to emphasize the role of the alumni as voluntary faculty that greatly enriches the body of instructors contributing to pre-graduate training but also their own scholar skills. Additionally, this constant interaction of the alumni with MedUM contributed to the understanding by MedUM faculty that there are specific needs in the postgraduate area that are not covered and for which the medical schools can contribute by providing simulation based courses. The role of the Alumni Medicine has been paramount in this interaction by providing a network and facilitating the flow of information between alumni and the school.

\section{CONCLUSION}

The main conclusion is that the constructive alignment of educational and assessment strategies towards the

\section{REFERENCES}

1. Frank JR, Snell L, Sherbino J, editors. CanMEDS 2015 Physician Competency Framework. Ottawa: Royal College of Physicians and Surgeons of Canada; 2015.

2. Miller GE. The assessment of clinical skills/competence/performance. Acad Med. 1990;65:S63-7.

3. Biggs J, Tang C. Teaching for quality learning at university. Maidenhead: McGraw-Hill and Open University Press; 2011.

4. Gonçalves M, Salgueira AP, Costa MJ, Frada T, Pereira VH, Pêgo JM, et al. Implementing a standardized patient program in a new medical school. Dundee: AMEE; 2010.

5. Gonçalves M, Gonçalves M, Sousa AL, Morgado P, Costa P, Cerqueira JJ. Development and validation of a new instrument to assess communication skills. Barcelona: Sociedad Española de Educación Médica; 2013.

6. Cerqueira JJ, Pereira VH, Morgado P, Sousa N, Costa MJ. Comparison of virtual patients and traditional case-based discussion in a neurology rotation. Dundee: AMEE; 2010.

7. Gomes SH, Folhadela T, Guimarães R, Sousa N, Pêgo JM. InAnesthesia course - introduction to clinical anesthesiology. Granada: SESAM; medical education continuum needs reflective thinking on the learners' needs and a sense of retribution from medical schools and medical doctors. The secondary gain of these initiatives is to provide opportunities for junior doctors to practice teaching and completing the circle of education that characterizes the medical profession.

\section{PROTECTION OF HUMANS AND ANIMALS}

The authors declare that the procedures were followed according to the regulations established by the Clinical Research and Ethics Committee and to the Helsinki Declaration of the World Medical Association.

\section{DATA CONFIDENTIALITY}

The authors declare having followed the protocols in use at their working center regarding patients' data publication.

\section{CONFLICTS OF INTEREST}

The authors declare that there are no conflicts of interest.

\section{FUNDING SOURCES}

No subsidies or grants contributed to this work.

2011.

8. Gomes SH, Oliveira V, Arantes S, Guimarães R, Folhadela T, Sousa N et al. InAnesthesia - advanced course. Stavanger: SESAM; 2012.

9. Salgueira AP, Cerqueira JJ, Sousa N, Costa MJ. The education purpose of a clinical skills centre: filling the learning gaps. Dundee: AMEE; 2008.

10. Cerqueira JJ, Salgueira AP, Taipa R, Sousa N, Costa MJ. Monitoring and improving neurological examination learning. Dundee: AMEE; 2008.

11. Gago M, Barros $P$, Abreu $P$, Lemos J, Morais $H$, Palavra F, et al. INeurology: an introductory course for neurology residents. London: EAN; 2016.

12. Bessa JM, Morgado P, Freitas D, Cerqueira J, Sousa N. I Congresso Nacional de Investigação em Educação Médica. Covilhã: FCS; 2014

13. Scoles P, Scoles P, Bessa JM, Castro G, Lemos AR, Costa MJ, et al. Congresso da Sociedade Anatómica Portuguesa. Lisboa: SAP; 2016.

14. Mariz J, Vilas-Boas A, Santa Cruz A, Gomes SH, Pêgo JM. Improve internal medicine skills for emergency department work - simulationbased training course. Congresso Nacional de Simulação Médica, $1^{\circ}$ Congresso da Sociedade Portuguesa de Simulação Aplicada às Ciências da Saúde. Coimbra: SPSim; 2012. 